\title{
Edycje florenckie i lukańskie w krakowskiej bibliotece w XVII wieku ${ }^{1}$
}

Biblioteka Pinocciego

Biblioteka, którą Girolamo Pinocci w momencie swojej śmierci w 1676 roku zostawił w całości trzem córkom, słynęła jako jeden $\mathrm{z}$ większych zbiorów ksiąg w Królestwie Polskim² ${ }^{2}$ Zazdrośnie strzeżona w specjalnie zarezerwowanej dla niej komnacie („camera della libraria”) w pięknym krakowskim pałacu zajmowanym przez rodzinę, chroniona przez masywne, zakratowane okna wstawione specjalnie w tym celu, zawierała mniej więcej dwa tysiące woluminów w ośmiu językach (z przewagą książek włoskich i łacińskich). Około 360 spośród nich przetrwało do dziś i znajduje się głównie w zbiorach Biblioteki Uniwersytetu Jagiellońskiego. Pinocci - odnoszący sukcesy kupiec, jeden z najbogatszych i najsławniejszych Włochów przebywających w Polsce w XVII stuleciu, był również człowiekiem o wielkich zainteresowaniach kulturalnych i intelektualnych (od alchemii począwszy) pielęgnowanych zgodnie z duchem czasu.

1 Za pomoc podczas pisania artykułu, którego pierwsza wersja ukazała się w Le livre italien hors d'Italie au XVIIe siecle. Actes du colloque du 23 au 25 avril 2009 réunis par Delphine Montoliu, Toulouse 2010, s. 151-176 („Collection de l'E. C. R. I. T.”, no 12), dziękuję Joannie Pypłacz z Gabinetu Starych Druków Biblioteki Jagiellońskiej w Krakowie.

2 Znaczenie zbioru akcentuje M. Brahmer. Por. Id. La bibliteca dei Pinocci. Un episodio nella storia degli italiani in Polonia, Roma 1959 („Accademia polacca di Scienze e Lettere. Bbiblioteca di Roma”). Inwentarz z 1704 roku wymienia 1707 książek, podzielonych na 25 działów (od pierwszego „Libri filosofici” do ostatniego „Libri misti”), i, oprócz tytułów, zawiera także informacje o miejscu i roku wydania. Por. K. Targosz, Hieronim Pinocci. Studium z dziejów kultury narodowej w Polsce $w$ XVII wieku, Wrocław-Warszawa-Kraków 1967, s. 117-222. 
Przez całe życie gromadził księgi drukowane i rękopiśmienne, ale także gazety, mapy, plany i projekty miast. Wiele z tych materiałów odziedziczył (dbał o nie z największą troską i strzegł przed prowizoryczną i mogącą je łatwo zniszczyć konserwacja) $)^{3}$, wiele natomiast zdobył sam. Nie spuszczał bowiem oka z katalogów księgarskich i katalogów targów we Frankfurcie ${ }^{4} \mathrm{i}$ albo zlecał zakupy swoim kontrahentom w Gdańsku, albo kupował książki osobiście od zaufanego sprzedawcy krakowskiego, który w jego księgach rachunkowych pojawia się pod imieniem Rupis. Poza tym, zbiory swoje uzupełnił podczas pobytu w Amsterdamie i Londynie, gdzie przebywał jako ambasador Jana II Kazimierza podczas wojny polsko-szwedzkiej (1658-1659). Wszystkie nabytki (podzielone wedle formatu) zapisywał Pinocci w rejestrach i inwentarzach, koncentrując się na tych, które umieszczał w skrzyniach w celu ich przewiezienia z miasta na wieś lub odwrotnie, bądź na tych, które zostawiał w swym domu w Warszawie (bywał w tym mieście często z powodu obowiązków na dworze królewskim) $)^{5}$. Tak samo postępował z księgami pożyczonymi choćby nawet innemu kupcowi. W ostatnim przypadku możemy zdobyć pożyteczne informacje (zazwyczaj niemożliwe do uzyskania) na temat obiegu książki, która mogła przechodzić z rąk do rąk bez żadnego śladu ${ }^{6}$. Chcąc

3 Por. A. Petrucci, Le biblioteche antiche, w: Letteratura italiana, vol. II: Produzione e consumo, Torino 1983, s. 546 („niszczenie prywatnych zbiorów mieszczan organicznie związane było z ich naturą, chaotycznym gromadzeniem, skromną objętością, ścisłą relacją łączącą księgi i osoby, które używały i traktowały książki jak zwykłe przedmioty gospodarstwa domowego").

4 Per un Catalogus librorum pro nundinis francofurtensibus vernalibus de anno 1657, $4^{\circ}$. Por. Kraków, Wojewódzkie Archiwum Państwowe (dalej jako WAP), Archiwum Pinoccich, IT 378, s. 553. Zob. także Catalogorum variorum in omni facultate ac lingua librorum quorum auctio habetur apud Ioannem Verhoeve bibliopolam anno 1658 exemplaria plura, w: K. Targosz, op. cit., nr 1752; Catalogus universalis pro nundinis francofurtensibus vernalibus de anno MDCLVII. Hoc est: Designatio omnium librorum qui hisce nundinis autumnalibus, vel novi, vel emendatiores et auctiores prodierunt [...], Francofurti, sum[p]tibus Heredum Sigismundi Latomi, anno MDCLVII, w: K. Targosz, op. cit., nr 1753 oraz egz. Biblioteki Jagiellońskiej (dalej jako BJ), sygn. Mag St Dr 585093 I.

5 Por. Registro de' libri stampati e manoscritti che restano in Varsavia nell'habitazione di mio dwor nella camera dietro alla mia stufa nella cassetta dipinta a fiori (Kraków, WAP, Archiwum Pinoccich, IT 405).

6 Por. K. Targosz, op. cit., s. 82; R. Chartier, Letture e lettori nella Francia dell'Antico Regime, tr. it., Torino 1988, s. 153 („Pożyczanie książek jest tak stare jak sama książka”). Świadectwa obiegu książek poprzez ich wzajemne pożyczanie w celu lektury lub 
rozeznać się wśród mniej więcej dwóch tysięcy tytułów — gdy nakładają się na siebie różne warstwy kultury europejskiej i nie brakuje nazwisk tak znanych jak Montaigne, Bodin, Kartezjusz, Grotius - trzeba zacząć od biografii kupca z Lukki i choćby tylko rzucić okiem na liczną kolonię włoską w Krakowie, kupiecką i nie tylko. Biblioteka Pinocciego jawi się jako niesamowity zbiór dzieł przekazywany z rąk do rąk w ciągu około stu lat tak, że jego dzieje, zaplątane niczym skomplikowane supły i delikatnie rekonstruowane, mogłyby stać się osobnym rozdziałem w historii komunikacji kulturalnej nowożytnej Europy. Kolekcja Pinocciego jest też istotna z powodu swojego umiejscowienia geograficznego na obrzeżach gęsto zaludnionej Europy. Mamy też do czynienia z biblioteką siedemnastowieczną, która zostawiła po sobie wyraźny ślad w postaci kolejnych, składających się na nią nabytków i która pod pewnymi względami staje się raczej zwierciadłem odbijającym intensywność kulturalną „,włoskiego” Krakowa pod koniec XVI stulecia niż obrazem aktywności wydawniczej Półwyspu Apenińskiego.

Pinocci, urodzony w Lukce w 1612 roku w rodzinie o skromnej przeszłości, stosunkowo niedawno przybyłej do miasta z gór, znalazł się w Krakowie jako młodzieniec, aby pracować w warsztacie swego ziomka. Odniósł wielki sukces $\mathrm{w}$ wielu różnych przedsięwzięciach, m.in. handlując luksusowymi tkaninami ${ }^{7}$. Krążąc nieustannie po organizowanych $\mathrm{w}$ państwie polskim targach (w tak zacofanej gospodarce jak polska zachowały one także do końca XVII wieku swoje znaczenie opierające się na sprzedaży wszystkiego i wszystkim), zawsze gotów ryzykować i zainwestować, nie tracił żadnej okazji do zarobku. W 1664 roku ożenił się z pasierbicą Raffaella Del Pace (zm. 1655) — zamożnego kupca florenckiego z drugiego pokolenia kupców włoskich z Krakowa - i właściwie po teściu odziedziczył wiele ksiąg, które utworzyły jego bibliotekę. Ten z kolei przejął je (wraz z kartoteką) ${ }^{8}$ po własnym

kopiowania są liczne. Na przykład, dla Lukki por. S. Polica, Le commerce et le prêt de livres à Lucques dans la première moitié du XVe siècle, „Médiévales”, 14, 1988, s. 33-46; http://www.persee.fr. W środowisku florenckim źródło wielu informacji stanowią ricordanze. Por. G. Fragnito, La Bibbia al rogo. La censura ecclesiastica e i volgarizzamenti della scrittura, Bologna 1997, s. 42-43.

7 Szerzej o charakterystyce handlowca por. R. Mazzei, Traffci e uomini d'affari italiani in Polonia nel Seicento, Milano 1983, s. 111-120.

8 O fizycznym przemieszaniu kartotek i książek przechowywanych przez kupców por. A. Petrucci, op. cit., s. 545. 
ojcu Luce (zm. 1609), jednym z najbardziej wpływowych kupców krakowskich w drugiej połowie XVI wieku, prowadzącym rozległe interesy sięgające aż do Litwy.

Ponieważ w innym miejscu, z powodu zainteresowań magią Pinocciego, zajmowaliśmy się jego biblioteką ${ }^{9}$, teraz skoncentrujemy się na edycjach włoskich, a w szczególności na tych wydanych we Florencji i Lukce.

Edycje florenckie

Między wydaniami włoskimi pierwszeństwo w bibliotece Pinocciego mają druki weneckie. W szczególności znajdziemy w księgozbiorze dobrze reprezentowanych i tak znanych wydawców jak Vincenzo Valgrisi, Francesco i Giordano Ziletti. Warto tylko przypomnieć, że Wenecja była miastem drukarni, gdzie wychodziły wszystkie nowości, lecz także niemal obowiązkowym przystankiem na drodze do Polski. Zatrzymując się w Wenecji, jeszcze przed załatwieniem interesów i spraw związanych z podróżą, krążąc między Rialtro a placem św. Marka, z łatwością można było kupić najrozmaitsze książki. Chociaż o edycjach weneckich będziemy mówić gdzie indziej, to musimy jednak odnieść się teraz do kilku $\mathrm{z}$ nich.

Różnorodność książek zgromadzonych w skrzyniach w domu Pinocciego, opublikowanych przez różne oficyny, odsłania — w perspektywie europejskiej - głęboko sięgające korzenie zitalianizowanego Krakowa, do którego się odnosimy i w którym, około połowy XVI wieku, prym wiedli mercatores florenccy. Mając na uwadze ten fakt, mogły się pojawić $\mathrm{w}$ omawianych zbiorach z pewnością kroniki lub historie miejskie, jak te autorstwa Giovanniego i Mattea Villanich ${ }^{10}$ — chociaż w kronice Mattea

9 Por. R. Mazzei, Argent et magie, entre affaires et culture en Europe centrale et orientalne (XVIe-XVIIe siècles), w: Commerce, voyage et expérience religieuse (XVIe-XVIIe siècles), sous la direction de A. Burkardt, avec la collaboration de G. Bertrand, Y. Krumenacker, Rennes 2007, s. 395-416.

10 O Giovannim Villanim (ok. 1280-1348) i jego Istorie fiorentine sin all'anno 1338, [b. m. i r. wyd.] por. K. Targosz, op. cit., nr 1022. Do tego dzieła nie możemy nie dołączyć innego pt. Historie Universali de suoi tempi di Giovan Villani cittadino fiorentino nuovamente ristampata con tavole necessarie e postille in margine delle cose notabili, fatte per M. Remigio fiorentino. Pinocci posiadał wenecką edycję tego utworu (in Venetia, ad instantia de Giunti di Fiorenza, MDLIX; por. K. Targosz, op. cit., nr 1023), której egzemplarz znajduje się w BJ (sygn. Hist. 6293, Hist. 6. 293). O dziele Mattea Villaniego La prima parte della cronica universale de suoi tempi (in Fiorenza, appresso 
Villaniego w rzeczywistości znajduje się wpis proweniencyjny odsyłający do Giovanniego Michela Bruta, weneckiego literata i innowiercy, który przebywał w stolicy Polski w czasach Stefana Batorego — zarówno jako potwierdzenie wartości produkcji związanej z okresem humanizmu florenckiego, jak i zapowiedź lepszych rarytasów w postaci innych edycji. $\mathrm{Z}$ dzieł Mattea Palmieriego, autora dialogów Della vita civile i Annales (znanych pod tytułem Historia Florentina), mamy tylko włoską wersję utworu (napisanego pod wpływem przyjaźni) La vita di Niccolò Acciaioli i połączonego w suplemencie z Istoria della casa de gli Ubaldini ${ }^{11}$. Chodzi o późnoszesnastowieczną edycję drukarza Bartolomea Sermartelliego (1588), mogącą mieć coś wspólnego z obecnością w Krakowie jednego z Ubaldinich, Urbana, który jako bardzo młody człowiek w 1570 roku przybył do miasta, rozwinął w nim działalność kupiecką trwającą aż do śmierci i polegającą na krążeniu między Krakowem a Lwowem ${ }^{12}$. Z utworów Luki Pulciego w bibliotece Pinocciego znalazł się Criffo Calvaneo, poemat fantastyczny pisany oktawą i ukończony przez brata Luki — Luigiego. Razem z nim mamy, pisaną również oktawą, deskrypcję uroczystości o wielkim znaczeniu dla historii Florencji, a mianowicie turnieju

Lorenzo Torrentino, MDLIII) por. K. Targosz, op. cit., nr 1024. Egzemplarz z wpisem proweniencyjnym Bruta znajduje się w BJ (sygn. Hist. 4018). „Istorie universali Villaniego znajdziemy w spisie ksiąg zredagowanym przez samego Pinocciego między «rzeczami włożonymi do różowego kufra rzymskiego (le robbe messe nel cofano rosso romano)»" (Kraków, WAP, Archiwum Pinoccich, IT 378). O szesnastowiecznych, florenckich i weneckich, edycjach Villaniego por. D. Moreni, Annali della tipografia fiorentina di Lorenzo Torrentino impressore ducale, ristampa anastatica a cura di M. Martelli. Firenze 1989, s. 242-246; I Giunti tipografi editori di Firenze, 1497-1570. Annali, a cura di D. Decia, R. Delfiol, L. S. Camerini, Firenze 1978, s. 163 (nr 303), 174 (nr 336), 234, 237; I Giunti tipografi editori di Firenze, 1571-1625. Annali, a cura di L. S. Camerini, Firenze 1979, s. 75 (nr 104), 88 (nr 137), 122 (nr 237).

11 Istoria della casa de gli Ubaldini, e de fatti d'alcuni di quella famiglia. Libro primo. Descritta da Giovambattista di Lorenzo Ubaldini. E la vita di Niccola Acciaioli Gran Siniscalzo de' Regni di Cicilia, e di Gierusalemme descritta da Matteo Palmieri. E l'origine della famiglia de gli Acciaioli, e i fatti degli uomini famosi d'essa, in Firenze, nella stamperia di Bartolommeo Sermartelli, MDLXXXVIII (por. K. Targosz, op. cit., nr 1012).

12 O Ubaldinich w Polsce od początku lat siedemdziesiątych XVI wieku por. R. Mazzei, Itinera mercatorum. Circolazione di uomini e beni nell'Europa centro-orientale: 1550-1650, Lucca 1999, s. 128, 141, 340. 
wygranego przez młodziutkiego Lorenza w 1469 roku $^{13}$. Z dzieł Pulciego nie brakuje nawet Morgante w wydaniu weneckim z 1551 roku $^{14}$. Upodobanie do poezji, także o tematyce religijnej, odzwierciedla anonimowy zbiór wierszy wielu autorów starożytnych i współczesnych zatytułowany Scelta di laudi spirituali $i^{15}$, który zawiera różne laudy ułożone przez Lorenza de' Medici i jedną Poliziana. Najwspanialszym „reprezentantem” humanistycznej kultury florenckiej na dworze Lorenza de' Medici, znajdującym się w bibliotece, jest liońska edycja dzieł Poliziana ${ }^{16}$. Nie umiemy nic powiedzieć o bliżej niezidentyfikowanym druku Libro poetico (1555), przypisywanym Lorenzo Torrentino ${ }^{17}$.

Nie można nie zauważyć obecności książki De Etruriae Guillaume’a Postela z dedykacją dla Cosima I dei Medici, jaką książęcy drukarz (Torrentino - właśc. flamandczyk Laurens van der Beke, pochodzący z Gemert w księstwie Brabancji, ale wcześniej aktywny w Bolonii; we Florencji pracował w latach $1547-1565)^{18}$ wydał w 1551 roku. Jak

13 Por. Criffo Calvaneo di Luca Pulci gentil'huomo fiorentino. Con la Giostra del magnifico Lorenzo de Medici. Insieme con le Epistole composte dal medesimo Pulci, in Fiorenza, nella stamperia de' Giunti, MDLXXII (por. K. Targosz, op. cit., nr 1447 oraz egz. BJ, sygn. Mag St Dr 593620; Liter. włoska 652).

14 Por. Morgante maggiore di Luigi Pulci fiorentino nuovamente stampato, \& con ogni diligenza corretto. A cui è aggiunta una bellissima tavola con la dichiaratione di tutti i vocaboli oscuri, che nell'opera si contengono, in Venetia, per Comin de Trino di Monferrato, MDLI (por. K. Targosz, op. cit., nr 1448 oraz egz. BJ, sygn. Mag St Dr 593618; Liter. włoska 653).

15 Por. Scelta di laudi spirituali. Di diversi eccellentissimi e devoti autori antichi, e moderni; nuovamente ricorrette e messe insieme, in Firenze, nella stamperia de' Giunti, MDLXXVIII (por. K. Targosz, op. cit., nr 1708 oraz egz. BJ, sygn. Mag St Dr 593643-44; Liter. włoska 679). Dzieło figuruje także w spisie ksiąg zinwentaryzowanych jako należące do projektu RASTA (Raccolte a stampa antologiche del Petrarchismo e della poesia italiana dal Cinque al Settecento, http://rasta.unipv.it/). Por. także S. Albonico, Ordine e numero. Studi sul libro del poesia e le raccolte poetiche nel Cinquecento, Alessandria 2006, s. 245.

16 Por. Angeli Politiani, Operum tomus primus [-tertius], epistolarum libros xiii ac miscellanelorum centuriam unam complectens, Lugduni, apud Seb. Gryphium, 1550 (por. K. Targosz, op. cit., nr 1832). Dzieło Poliziana („Politiani Operum tom. 1. 2. 3. octavus”) znajdziemy w spisie ksiąg między „,rzeczami włożonymi do różowego kufra rzymskiego" (por. Kraków, WAP, Archiwum Pinocchich, IT 378, 556).

17 Por. K. Targosz, op. cit., nr 1471. Żadnego rezultatu nie przyniosły poszukiwania w Edit 16, http://edit16.iccu.sbn.it/.

18 O jego działalności por. D. Moreni, op. cit.; F. Ascarelli, La tipografia cinquecentina italiana, Firenze 1996, s. 18-139; A. Nuovo, C. Coppens, I Giolito e la stampa 
warto zauważyć, dzieło Postela zaliczało się do tego prądu kulturowego, który, opiewając mit o początkach żydowsko-etruskich, zmierzał do odnowienia autochtonicznej tradycji Toskanii w celu legitymizacji nowych form władzy ${ }^{19}$.

Florentyńczycy napływający do Krakowa od połowy XVI wieku i później (czyli wtedy, gdy głównym celem kupców opuszczających w interesach miasto nad rzeką Arno był jeszcze Lion) zazwyczaj zostawali w nim do końca życia, choć zdarzało sie, że niejednokrotnie wracali do Florencji po to, by: załatwić jakieś sprawy rodzinne, brać udział w procesach w trybunale cechu kupieckiego (Mercanzia), kontaktować się z dostawcami, ponieważ wszyscy — w mniejszym lub większym stopniu — trudnili się handlem luksusowymi tkaninami. Często w momencie wyjazdu w ich bagażu znajdowały się pewne książki, np. dzieła autorów przechodzące z jednego pokolenia na drugie, jak książki dwóch Villanich (tym bardziej, że byli oni obecni w klimacie kulturalnym Florencji czasów Cosima I dzięki edycji Torrentina i — przede wszystkim - kolejnych przygotowanych przez Giuntiego). Wspomnimy tu tylko o kolejnym wydaniu utworu Mattea Villaniego. W jego przygotowanie był zaangażowany Vincenzo Borghini (Giovanni e Matteo Villani należeli do twórców cieszących się szczególnym zainteresowaniem tego uczonego erudyty i filologa oraz funkcjonariusza dworu medycejskiego ${ }^{20}$. Wśród książek „podróżnych” trzeba też wymienić $H i$ storia monastica Pietra Calzolaia ${ }^{21}$, opublikowaną po raz pierwszy przez Torrentina w 1561 roku, czyli dzieło, w którym tradycja religijna splata się nieustannie z wpływami nowelek i przykładów rodem z Boccaccia

nell'Italia del XVI secolo, Genève 2005, s. 160-161.

19 Por. De Etruriae regionis, quae prima in orbe europaeo habitata est, originibus, institutis, religione \& moribus, \& imprimis de urei saeculi doctrina, et vita praestantissima, quae in divinationis sacrae usu posita est, Gulielmi Postelli commentatio, Florentiae, [Lorenzo Torrentino], MDLI (por. K. Targosz, op. cit., nr 984). Por. edycję krytyczną dzieła przygotowaną przez G. Cipriani (Roma 1986). Szerzej o samym zagadnieniu por. C. Vasoli, Postel e il „mito dell'Etruria”, w: La cultura delle corti, Bologna 1980, s. 190-218.

20 Por. Fra lo „Spedale” e il Principe. Vincenzo Borghini, filologia e invenzione nella Firenze di Cosimo I. Atti del Convegno (Firenze, 21-22 marzo 2002), a cura di G. Bertoli, R. Drusi, Padova 2005.

21 Por. Historia monastica, di D. Pietro Calzolai, da Buggiano di Toscana, monaco della Badia di Firenze, della Congregazione di Monte Cassino, distinta in cinque giornate [...], in Firenze, appresso Lorenzo Torrentino, MDLXI (por. K. Targosz, op. cit., nr 784 oraz egz. BJ, sygn. Hist. 1983). 
lub Aretina ${ }^{22}$. W interesującym nas gronie znajdowała się też potwierdzająca związek z miastem rodzinnym i ciesząca się uznaniem książka Alessandra Ceccherelliego Delle azioni et sentenze del signor Alessandro de’ Medici primo duca di Firenze, sławiąca wolność i mądrość pierwszego księcia Florencji (wydawano ją wielokrotnie w XVI stuleciu tak we Florencji, jak w Wenecji) ${ }^{23}$ lub gramatyka języka florenckiego dla uczonych, jak Institutionum florentiae linguae libri duo akademika Eufrosina Lapiniego (1520-1571). Ta ostatnia opatrzona jest wpisem proweniencyjnym Raffaella Del Pace, a w bibliotece znalazła się jej trzecia edycja z 1598 roku $^{24}$, czyli z okresu, w którym wielu florentyńczyków z Krakowa krążyło tam i z powrotem między Italią a Polską.

Debata wokół nowych idei religijnych pokazała, że przebywający w Krakowie Włosi zajmowali wobec problemów religijnych różne stanowiska i że liczna kolonia kupiecka prezentowała się jako bardzo różnorodna pod względem wyznaniowym. Żywe dyskusje o kwestiach wiary, które musiały być prowadzone na Wielkim Rynku - miejscu spotkań wszystkich - lub w zaciszu sklepów, znalazły odzwierciedlenie w bibliotece Pinocciego, gdzie prawdopodobnie trafiły książki braci Franco ożenionych z dwiema siostrami z domu Del Pace ${ }^{25}$. Bardziej znany z tej dwójki, Pietro, przeszedł na kalwinizm, a jego imię łączy się z modlitewnikiem w języku włoskim „nie pozbawionym pewnych ambicji literackich i przepełnionym głęboką i prostą religijnością"26.

22 Jako przykład odwołujący się do starej tradycji uroczystego wjazdu do miasta nowego biskupa, który poprzedzał podniosłą ceremonię zaślubin duchownego z mniszką por. pracę: G. Zarri, Recinti. Donne, clausura e matrimonio nella prima età moderna, Bologna 2002, s. 316-317. O podziwie, jaki żywiły dla Calzolaia środowiska kulturalne o średnim poziomie intelektualnym, por. P. Pastore, Calzolai Pietro, w: Dizionario Biografico degli Italiani, vol. XVII, Roma 1974, s. 62-63 (dalej jako DBI).

23 Florencja, [b. r. wyd.]. Por. K. Targosz, op. cit., nr 790. Szerzej o tym por. M. Ariani, Memoria e persuasione, w: Storia letteraria d'Italia, nuova edizione a cura di A. Balduino, Il Cinquecento, a cura di G. Da Pozzo, t. 2: La normativa e il suo contrario. Le nuove regole e l'estensione dell'enologia, Padova-Milano 2007, s. 1214.

24 Institutionum Florentinae linguae libri duo Euphrosyni Lapinij ad sereniss. Reginam Ioannam Austriacam [...], tertia editio, Florentiae, apud Philippum Iunctam, MDIIC (por. K. Targosz, op. cit., nr 1237 oraz egz. BJ, sygn. Mag St Dr Gramatyka 835 II). Pierwsza edycja ukazała się w roku 1569 „apud Iuntas”.

25 Szerzej na ten temat por. R. Mazzei, La trama nascosta. Storie di mercanti e altro (secoli XVI-XVII), Viterbo 2006, s. 191-192.

26 D. Caccamo, Eretici italiani in Moravia, Polonia, Transilvania (1558-1611), Firenze-Chicago 1970, s. 89-93. 
Aby potwierdzić zainteresowania tematyką religijną (również heterodoksyjna), wystarczyłoby wspomnieć o bogactwie materiałów biblijnych, w jakie obfituje biblioteka, $\mathrm{z}$ różnymi edycjami Biblii na czele, co zdaje się potwierdzać powszechną praktykę lektury tego dzieła ${ }^{27}$. Jeśli chodzi o horyzont religijny, to sygnalizujemy obecność wśród wydań florenckich utworu słynnego polemisty, sieneńczyka Ambrogia Catarina ( vel Lancillotta Politiego), najpierw zwolennika Savonaroli, a potem jego zaciekłego wroga. Chodzi o krótką Excusatio disputationis contra Martinum ad universas ecclesiae, którą dominikanin ze Sieny wymierzył przeciwko Lutrowi i w której potwierdzał autorytet i nieomylność papieża $^{28}$. Książka ta, wydrukowana pod koniec kwietnia 1521 roku przez spadkobierców Giunty (dopiero po śmierci Filippa w 1517 roku kontynuowali oni prace drukarskie jego oficyny aż do 1532 roku), jest jedną z najstarszych w bibliotece Pinocciego. $Z$ drugiej strony plasują się cztery traktaty Gaspara Contariniego w pierwszym florenckim wydaniu z 1553 roku $^{29}$, czyli dziesięć lat po śmierci weneckiego kardynała. Był on, jak wiadomo, jednym z największych przedstawicieli nurtu dążącego do kompromisu doktrynalnego między katolikami a protestantami. W żarliwe uczucia religijne wprowadza także dzieło Libro della vanità del mondo portugalskiego franciszkanina Diega de Estella, przetłumaczone przez Gremia Forestiego i opublikowane po raz pierwszy w 1573

27 O obecności Biblii w bibliotece por. K. Targosz, op. cit., s. 204-205. Warto także przypomnieć, że po soborze trydenckim, w połowie XVI wieku, Włochy zaliczały się do tych krajów europejskich, w których rozpowszechniła się praktyka czytania Biblii. Por. G. Fragnito, op. cit., s. 24.

28 Florentiae, per haeredes Philippi Iuntae, anno Domini MDXXI, die ultimo Aprilis (por. K. Targosz, op. cit., nr 1580). O tym dziele por. G. Caravale, Sulle tracce dell'eresia. Ambrogio Catarino Politi (1484-1553), Firenze 2007, s. 32-33.

29 Gasparis Contareni cardinalis De sacramentis christianae legis, et catholicae ecclesia libri quattuor. Eiusdem Katechesis sive christiana instructio. Eiusdem de protestate pontificis quod divinitus sit tradita commentariolus ad Nicolaum Teupolum. Eiusdem Conciliorum magis illustrium summa ad Paulum tertium pontificem maximum, Florentiae, apud Laurentium Torrentinum, MDLIII (por. K. Targosz, op. cit., nr 1585 oraz egz. BJ, sygn. Theolog. 1097 I, Theolog. 1097). O najsłynniejszym przedstawicielu kontrreformacji por. G. Fragnito, Gaspare Contarini. Un magistrato veneziano al servizio della cristianità, Firenze 1988. O znaczeniu edycji florenckiej tych właśnie dzieł, „które odbijają zapał apologetyczny i polemiczny lub niewzruszone zaufanie doktrynom Kościoła rzymskiego", por. ibidem, s. 316-317. 
roku przez Giorgia Marescottiego ${ }^{30}$. Ten drukarz i wydawca francuskiego pochodzenia (Georges Marescot), który działał we Florencji od 1563 roku, uznawany jest za jednego z aktywniejszych typografów toskańskich w drugiej połowie XVI stulecia.

Wśród szesnastowiecznych edycji znajdują się też dzieła klasyków. Na pierwszym miejscu trzeba wymienić Senekę i przekład jego De benefizii autorstwa Benedetta Varchiego zadedykowany księżnej Eleonorze. Dwa kolejne i nieodległe w czasie wydania (weneckie z 1564 roku i florenckie z 1574 roku) potwierdzają ogromny sukces utworu ${ }^{31}$. Trzeba też dodać, że Seneka cieszył się dużą popularnością, o czym świadczy jego znajomość nawet w niezbyt wyrafinowanych pod względem kulturalnym środowiskach. Cytuje go, na przykład, najbogatszy i najsłynniejszy z kupców włoskich działających w Polsce w drugiej połowie XVI wieku — toskańczyk Sebastiano Montelupi (pochodzący z Bibbony w kapitanacie Campiglia) w liście z września 1585 roku do Franciszka I. Starając się o wielkoksiążęce wsparcie dla swojej sprawy w sporze, który toczył się we florenckim sądzie cechu kupieckiego, dodaje: „Istnieje sentencja Seneki, że należy karać złych po to, by wzbudzać lęk u dobrych" ${ }^{32}$. Warto tu nadmienić, iż cytaty, jakie możemy znaleźć w pismach kupieckich, sugerują w ogóle mnemotechniczne przyswajanie czytanych tekstów, warunkowane poprzez mniej lub bardziej powtarzającą się lekturę ograniczonej liczby ksiąg. Praktykę tę, w przypadku Montelupich, potwierdzają, jak się zdaje, inne listy członków tej rodziny wysyłane na dwór

30 Libro della vanità composto dal R. P. F. Diego di Stella dell'ordine di S. Francesco Osservante. Diviso in tre parti [...] nuovamente tradotto do spagnolo in lingua toscana da Gremia foresti, in Fiorenza, appresso Giorgio Marescotti, 1573 (por. K. Targosz, op. cit., nr 1717 oraz egz. BJ, sygn. Teologia 4309). O działalności Marescottiego por. R. Delfiol, I Marescotti, librai, stampatori ed editori a Firenze tra Cinque e Seicento, „Studi secenteschi”, XVIII, 1977, s. 147-204; G. Guarducci, Annali dei Marescotti tipografi editori di Firenze (1563-1613), Firenze 2001; G. Bertoli, Autori ed editori a Firenze nella seconda metà del sedicesimo secolo: il caso di Marescotti, „Annali di Storia di Firenze", 2007, II: http://www.dssg.unifi.it?SDF/annali/annali2007.html (jeśli chodzi o druk Libro della vanità... por. s. 105, przyp. 35).

31 Seneca, De benefizii tradotto in volgar fiorentino da messer Benedetto Varchi, in Firenze, [Lorenzo Torrentino], 1554 (por. K. Targosz, op. cit., nr 505). O edycjach por. D. Moreni, op. cit., s. 249.

32 „E sentenza di Seneka che si deve gasigare i cattivi per tenere in timore i buoni” (Korespondencja Sebastiana i Valeria Montelupich (1576-1609), ed. D. Quirini-Popławska, Wrocław-Warszawa-Kraków-Gdańsk-Łódź 1986, s. 35). 
toskański, które charakteryzuje, w przytaczanych tu i tam fragmentach, język nawiązujący do biblijnych wyobrażeń czy Księgi Psalmów i świadczący o dobrym rozeznaniu w Piśmie Świętym.

Po Senece mamy Tacyta i jego L'imperio di Tiberio Cesare scritto da Cornelio Tacito nelli Annali (w wydaniu Giunty z 1600 roku) ${ }^{33}$. Dla uzyskania pełniejszego obrazu popularności Tacyta wśród przebywających w Krakowie florentyńczyków w dalszej kolejności zostaną omówione edycje weneckie. Teraz ograniczymy się do przywołania Annali z 1582 roku oraz Annali i Historie z 1620 roku (wszystkie wydrukowane przez Giuntich) ${ }^{34}$. Wśród wydań weneckich nie możemy pominąć autora tak typowego dla historiografii klasycznej jak Liwiusz i jego Deche chętnie odkrywane przez szesnastowiecznych lektorów. W bibliotece Pinocciego znajdujemy to dzieło w tłumaczeniu Iacopa Nardiego, opublikowane przez Giuntich w Wenecji w 1554 roku $^{35}$, ale mamy także utwory Liwiusza w innych edycjach szesnasto- i siedemnastowiecznych potwierdzających niesłabnące zainteresowanie twórczością tego historyka ${ }^{36}$. Uprzedzając wreszcie dalszą część artykułu, dodać trzeba, że w bibliotece Pinocciego, wśród edycji lukańskich, pojawiają się Opere morali (Moralia) Plutarcha, wytłoczone w Lukce przez Vincenza Bus-

33 L'imperio di Tiberio Cesare scritto da Cornelio Tacito nelli Anali espresso in lingua fiorentina propria da Benedetto Davanzati Bostichi, in Fiorenza, per Filippo Giunti, MDC (por. K. Targosz, op. cit., nr 1005).

34 Gli Annali di Cornelio Tacito, cavalier romano de' fatti, e guerre de' Romani [...] Nuovamente tradotti di latino in lingua toscana da Giorgio Dati fiorentino, Venetia, appresso Bernardo Giunti e fratelli, MDLXXXII (por. K. Targosz, op. cit., nr 1004); Opere di Cornelio Tacito, Annali, Historie [...], in Venetia, appresso i Giunti, MDCXX (por. ibidem, nr 728).

35 Le Deche di T. Livio padovano delle Historie romane, tradotte nella lingua toscana da M. Iacopo Nardi cittadino fiorentino [...], in Venetia, nella stamperia di Giunti, MDLIII (por. K. Targosz, op. cit., nr 893 oraz egz. BJ, sygn. Łacina 2723 III). O popularności dzieła Liwiusza por. G. Billanovich, La tradizione del testo di Livio e le origini dell'Umanesimo, vol. 1: Tradizione e fortuna di Livio tra Medioevo e Umanesimo, Padova 1981.

36 Titi Livii Patavini libri omnes qui ad nostrua aetatem pervenerunt, Francofurti, P. Fischerus, 1552 (por. K. Targosz, op. cit., nr 895); Titi Livii Patavini Historiarum libri VI, Amstelodami, apud Iohannem Ianssonium, 1661 (por. ibidem, nr 894); Orationes T. Livii Patavini ex eius, qui extant, libris [...], Romae, tipys Iacobi Mascardi, 1618 (por. ibidem, nr 1292). 
draghiego w 1560 roku $^{37}$. Przekład był dziełem Ludovica Domenichiego, literata z Piacenzy, znanego z działalności inkwizycyjnej, który we Florencji współpracował czynnie z Torrentinem, redagując ważną serię edycji i translacji na język włoski ${ }^{38}$.

Wśród wydań florenckich znajdziemy także teksty dwóch bardzo popularnych autorów jak Della Casa i Paolo Giovio, obecne również w innych edycjach. Z dzieł Giovanniego Della Casa mamy w bibliotece florencką edycję Galateo z 1578 roku (autor zmarł w 1556 roku) Bartolomea Sermartelliego, typografa specjalizującego się przede wszystkim $\mathrm{w}$ utworach $\mathrm{w}$ volgare i lokalnego pochodzenia (jak przywoływana wyżej Istoria della casa de gli Ubaldini) lub religijnych, oraz edycję rzymską łacińskiego tłumaczenia z końca wieku XVI - Galatheus, sive de moribus liber italicus ${ }^{39}$. Z dzieł Giovia pojawiają się Historie w przekładzie Domenichiniego wydrukowane przez Torrentina w 1558 roku $^{40} \mathrm{i}$ dwie edycje weneckie, Gli elogi degli uomini illustri di guerra i Ragionamento sopra $i$ motti e disegni e d'arme ${ }^{41}$.

37 Opere morali di Plutacho, nuovamente tradotte per M. Lodovico Domenichi, cioè il Convito de' sette savi. Come altri possa lodarsi da se stesso senza biasmo Della Garrulità, ovvero ciccaleria, in Lucca, per Vincenzo Busdragho, MDLX (por. K. Targosz, op. cit., nr 497 oraz egz. BJ, sygn. Philolog. gr. 1246). Zob. także edycje frankfurckie: Plutarchi Chaeronensis Aethicorum sive moralium pars II [...] Guilielmo Xylandro Augustano interprete, Francofurti, typis Ioannis Saurij, impensis Rulandiorum, et Nicolai Rothij, 1603 (por. K. Targosz, op. cit., nr 495); Plutarchu Chaeronensis Moralia, quae usurpantur [...]. Omnes de Graeca in Latinam linguam trasscripti summo labore, cura, ac fide Guiliel. Xylandro Augustano interprete, Francofurti, typis Ioannis Saurij, impensis Rulandiorum, et Nicolai Rothij, 1603 (por. ibidem, nr 496).

38 O Domenichim i jego współpracy z Torrentinem por. M. Firpo, Gli affreschi di Pontormo a San Lorenzo. Eresia, politica e cultura nella Firenze di Cosimo I, Torino 1997, s. 364 i n. passim.

39 Il Galatheo di M. Giovanni Della Casa, o vero Trattato de' costumi, e modi che si debbono tenere, o schifare nella comune conversazione, in Firenze, appresso Bartolomeo Sermartelli, 1578 (por. K. Targosz, op. cit., nr 440); Ioannis Casae, Galatheus, sive de moribus liber italicus. A Nicolao Fierberto anglo latine expressus, Romae, apud Dominicum Giliottum, 1595 (por. ibidem, nr 439).

40 La Prima parte dell'Historie del suo tempo do Mons. Paolo Giovio da Como vescovo di Nocera, tradotte per M. Lodovico Domenichi, \& da lui di nuovo rivedute, \& corrette [...], in Fiorenza, per Lorenzo Torrentino, 1558 (por. K. Targosz, op. cit., nr 840).

41 Ragionamento di Monsignor Paolo Giovio sopra i motti, et disegni d'arme et d'amore che communemente chiamano imprese con un discorso di Girolamo Ruscelli, intorno allo stesso soggetto, in Venetia, appresso Giornado Ziletti al segno della stella, 1560 (por. K. Targosz, op. cit., nr 462 oraz egz. BJ, sygn. Liter. włoska 185). Gli elogi. Vite brevemen- 
Wśród szesnastowiecznych edycji florenckich znajdują się dwa dzieła (o lukańskim pochodzeniu) matematyka i astronoma Egnazio Dantiego (1536-1586). W edycji Giuntich z 1573 roku pojawia się La Sfera ${ }^{42}$, przekład z Proklosa, w którym widnieje stary zapis proweniencyjny, nieudolnie skreślony i odsyłający do znanej rodziny z Lukki (Guinigi). Również z tej samej oficyny mamy dwa egzemplarze (z 1569 i 1578 roku) Trattato dell'uso et della fabbrica dell'astrolabio ${ }^{43}$. Bez wątpienia astrolabium, instrument niezbędny „for casting the houses” ”4, był przedmiotem szczególnego zainteresowania ze strony kupca z Lukki, wykorzystywanym do naukowych eksperymentów. Danti skonstruował też dwa astrolabia we Florencji: jedno dla Cosima I, a drugie dla kardynała Ferdinanda dei Medici ${ }^{45}$. Na frontyspisie Trattato dell'uso et della fabbrica dell'astrolabio z 1569 roku pojawia się nota proweniencyjna przypisywana nieznanemu bliżej Pissiniemu z Lukki, z informacją o 1589 roku, ale sub verso mamy zaskakującą notkę samego Pinocciego: „Hyeronimi Pinocij Lucensis Patritij, 1628”. A zatem, w 1628 roku był on tylko ambitnym, szesnastoletnim młodzieńcem, prawie na pewno ledwo co opuścił dom rodzinny, aby zmierzyć się ze swoim losem, a jego położenie dalekie było od tego, co opowiadał. Wprost przeciwnie. W ojczyźnie jego rodzina nie miała nigdy dojścia do żadnych funkcji publicznych i nawet nie była w jakikolwiek sposób znana.

te scritte d'huomini illustri di guerra, antichi et moderni, di Mons. Paolo Giovio vescovo di Nocera [...] tradotte per M. Lodovico Domenichi, in Vinegia, appresso Francesco Lorenzini da Turino, 1559 (por. ibidem, nr 841 oraz egz. BJ, sygn. Cim 1900, Hist. 3732).

42 La Sfera di Proclo Liceo tradotta da maestro Ignatio Danti; cosmografo del serenissimo Gran Duca di Toscana. Co le annotazioni, \& con l'uso della sfera del medesimo, in Fiorenza, nella stamperia de' Giunti, MDLXXIII (por. K. Targosz, op. cit., nr 235 oraz egz. BJ, sygn. Mag St Dr 593796 II, Mathes. 1123).

43 Trattato dell'uso et della fabbrica dell'astrolabio. Di F. Egnatio Danti dell'Ordine di S. Domenico. Con l'aggiunta del planisferio del Roias, in Fiorenza, appresso i Giunti, MDLXVIIII (por. K. Targosz, op. cit., nr 171 oraz egz. BJ, sygn. Mag St Dr 593249 II, Mat. 439); Trattato dell'uso e fabbrica dell'astrolabio. Di M. Egnatio Danti dell'Ordine di S. Domenico. Con il planisferio del Roias [...], in Firenze, appresso i Giunti, 1578 (por. ibidem, nr 107).

44 J. D. North, Horoscopes and history, London 1986, s. 67-69.

45 Por. F. P. Fiore, Danti Egnazio, w: DBI, vol. XXXII, 1986, s. 660 (całe hasło na s. 659-663). 
W bardzo powszechne wśród kupców zainteresowanie dziełami geograficznymi, w sposób szczególnie wyraźny cechujące Pinocciego, który podczas pobytu w Amsterdamie zakupił pełne garście prac takich jak mapy i plany miast, wpisuje się anonimowy i dziś bardzo rzadki Breve trattato delle città nobili del mondo et di tutta l'Italia, wydany we Florencji w małym formacie w 1574 roku $^{46}$.

Wśród florenckich edycji z XVI wieku natychmiast rzucają się w oczy te związane z naukowymi pasjami Pinocciego. Prawdą jest, że przez całe prawie życie z wielką korzyścią prowadził działalność kupiecką na rozległym obszarze od Krakowa przez Warszawę po Lwów i udawało mu się także rozwijać swoje zainteresowania matematyką, astronomią, chemią, a oprócz tego - alchemią i medycyną. Wystarczy wspomnieć przyjaźń łączącą go z tak wszechstronnym naukowcem jak Tito Livio Burattini, niemal jego rówieśnikiem (młodszym o pięć lat). Burattini był autorem traktatu meteorologicznego Misura universale, opublikowanego w Wilnie w 1675 roku. Proponował w nim przyjęcie za jedną miarę liniową długości wahadła uderzającego dokładnie przez sekundę ${ }^{47}$. Sam Pinocci jawi się nam też jako postać zaangażowana w naukowe eksperymenty ${ }^{48}$. Aby zrozumieć znaczenie, jakie mogła mieć dla rozwoju jego zamiłowań kulturalnych sieć powiązań, którą rozwinął mimo mieszkania na peryferiach Europy w Krakowie, warto wiedzieć, że Łukasz Opaliński, marszałek wielki koronny w latach 1649-1662 i bliski Pinoccie-

46 Breue trattato delle città nobili del mondo, et di tutta Italia, con la lunghezza, et larghezza di essa, confini, sito, et provincie [...], in Fiorenza, [b. druk.], 1574 (por. K. Targosz, op. cit., nr 775). Do naszych czasów w Edit 16, http://edit16.iccu.sbn.il/ zachowały się tylko cztery zinwentaryzowane kopie. Un Breve trattato delle città nobili del mondo, et di tutta Italia, con la lunghezza, et larghezza di essa, confini, sito, et provincie [...], przypisywany jest akwilejskiej drukarni Giuseppe Cacchiego (1566). Por. W. Capezzali, Margherita d'Austria e la produzione tipografica aquilana nel XVI secolo, w: Margherita d'Austria. Costruzioni politiche e diplomazia tra corte Farnese e Monarchia spagnola, a cura di S. Mantini, Roma 2003 („Europa delle Corti. Centro strudi sulle società di antico regime”, „Biblioteca del Cinquecento”, vol. 109), s. 190.

47 Por. C. Barocas, D. Caccamo, A. Ingegno, Burattini Tito Livio, w: DBI, XV, 1972, s. 394-399.

48 Do niego („Domino Hyeronimo Pinocci, liberalium artium cultori eximio”) odnosi się Valeriano Magni, pisząc z Warszawy do matematyka i fizyka Gillesa Personne’a de Roberval z Paryża (list z 15 XI 1647 roku). Por. Corespondance du P. Marin Mersenne religieux minime commencée par Paul Tannery, publiée et annotéee par C. De Waard, A. Beaulieu, Paris, 1983, XV (1647), s. 529. 
mu autor pism politycznych, nie zapominał o nim w korespondencji z gdańskim zwolennikiem socynianizmu - Martinem Ruarem (15881657) ${ }^{49}$. Biorąc pod uwagę zainteresowania naukowe właściciela, nie zaskakuje obecność w jego bibliotece dzieł: Saggi di naturali esperienze fatte nell'Accademia del Cimento ${ }^{50}$ napisanych przez sekretarza Akademii - Lorenza Magalottiego oraz Esperienze intorno alla generazione degli insetti ${ }^{51}$ Franceska Rediego (1626-1698), toskańskiego lekarza i przyrodnika, ale też pisarza-naukowca najbardziej reprezentatywnego dla tego okresu. Pasje astronomiczne odbija roczny kalendarz Antonia Carnevale (1611-1678) Gli Arcani delle stelle intorno a più notabili eventi nelle cose del mondo per l'anno $1658^{52}$, a z zamiłowaniami medycznymi wiąże się Apologeticon in Fortunii Liceti Mulctram vel de duplici calore ${ }^{53}$ Giovanniego Nardiego (ok. 1580-ok. 1655), mało znanego lekarza i fi-

49 Por. „Ergo per litteras cum quodam cive \& mercatore Cracoviensi, quem vocant D. Hieronymus Pinocci Italus, ut factori suo Varsaviae manenti iniungeret scripta D. V. quandocunque illa eo destinaveris, Cracov. transmittere, unde facili negotio mihi postmodum reddantur" (Martini Ruoari, nec non H. Grotii, M. Mersenni, M. Gittichii et Naerani aliorumque virorum doctorum [...] epistularum selectarum centuria. In quibus res magni in religione momenti inter diversarum sententiarum atque sectarum nomine tractantur \& examinantur, Amstelodami, apud Davidem Ruarum, 1677, s. 404. O Ruarze por. P. Bietenholz, Daniel Zwiker, 1612-1678. Peace, tolerance and God the One and Only, Firenze 1997, passim. O związkach Opalińskiego z Pinoccim por. K. Targosz, op. cit., passim; J. Bieniarzówna, J. M. Małecki, Dzieje Krakowa. Kraków w wiekach XVI-XVIII, vol. 2, Kraków 1984, s. 520-521.

50 Saggi di naturali esperienze fatte nell'Accademia del Cimento sotto la protezione del serenissimo principe Leopoldo di Toscana e descritte dal segretario di essa Accademia, in Firenze, per Giuseppe Cocchini all'insegna della Stella, 1666 (por. K. Targosz, op. cit., nr 76). Dzieło to - wynik doświadczeń Accademia del Cimento, założonej w 1657 roku przez księcia Leopolda, brata Ferdinanda II — Medyceusze razem z innymi dziełami posłali Burattiniemu. Por. C. Barocas, D. Caccamo, A. Ingegno, op. cit., s. 397. 51 Esperienze intorno alla generazione degl'insetti fatte da Francesco Redi accademico della Crusca, e da lui scritte in una lettera all'illustrissimo aignor Carlo Dati, in Firenze, all'insegno della Stella, 1668 (por. K. Targosz, op. cit., nr 71 oraz egz. z BJ, sygn. Zool. 442 III Mag St Dr, Zool. 442).

52 Firenze, [Francesco Onofri], 1658 (por. K. Targosz, op. cit., nr 167). Drukarz Francesco Onofri specjalizował się w edycjach dzieł astrologicznych i znaczną część wydawanych przez niego od 1656 roku utworów stanowiły roczne kalendarze. Por. R. L. Bruni, Editori e tipografi a Firenze nel Seicento, „Studi secenteschi” XLV, 2004, s. 396.

53 Ioannis Nardii, Philosophi \& Medici Florentini Apologeticon in Fortunii Liceti Mulctram vel de duplici calore, Florentiae, typis novis Amatoris Massae, \& soc., 1638 (por. 
lozofa florenckiego. Dzieło jego nawiązywało do dialogu Mulctra, sive De duplici calore corporum naturalium, wydanego w Udine dwa lata wcześniej, w 1636 roku. Jego autorem był słynny medyk i arystotelik Fortunio Licetti ${ }^{54}$.

Znajdujemy wreszcie w bibliotece utwory okolicznościowe lub dewocyjne pozwalające odtworzyć fragmentaryczny obraz Toskanii medycejskiej. Warto tutaj wspomnieć, że zazwyczaj florentyńczycy przebywający w Krakowie utrzymywali bardzo intensywne kontakty z wielkoksiążęcym dworem, o czym świadczy korespondencja z sekretarzami i samym wielkim księciem, którego dwór był w XVI wieku jednym z najlepiej poinformowanych o sytuacji w Polsce. Jeden z druków okolicznościowych to Descrizione delle feste ${ }^{55}$ - szczegółowe świadectwo ważnego dworskiego wydarzenia, czyli ślubu syna Ferdinanda II, przyszłego Cosima II, z arcyksiężną Austrii, który z wielkim przepychem odbył się w 1608 roku. Do dzieł dewocyjnych zaliczyć należy Idea della cristiana sapienza Baccia Bandinelliego, reprezentującego „rodzaj dewocyjnej erudycji”"56, oraz I trionfi di santa Maria Maddalena de’ Pazzi

K. Targosz, op. cit., nr 55 oraz egz. BJ, sygn. Philosophia 2407 II). Pochodzący z Forli Amadore Massi działał we Florencji w latach 1636-1654.

54 Z utworów Fortunia Licetiego (1577-1657), przyjaciela Galileusza, z którym toczył spory, w bibliotece Pinocciego znajduje się Litheosphorus sive de lapide Bononiensi, Utini, ex typographia Nicolai Schiratti, 1640 (por. K. Targosz, op. cit., nr 42), czyli dzieło o tak zwanej „pietra lucifera di Bologna”. „W rozdziale swego utworu, poświęconego szaremu światłu, które można spostrzec po ciemnej stronie księżyca, zwłaszcza kiedy znajduje się w bliskiej koniunkcji ze słońcem, Liceti stara się obalić tezę Galileusza (wyrażoną w Sidereus nuncius) twierdzącego, że zjawisko to nie jest niczym innym jak tylko efektem odbicia się na księżycu promieni słonecznych pochodzących z ziemi. Liceti natomiast fenomen ten uważał za luminescencję wytworzoną przez atmosferę wokół księżyca, która, tak samo jako „pietra lucifera” z Bolonii, posiadała zdolność przechowywania przez pewien czas światła docierającego z wyprzedzeniem ze słońca" (G. Ongaro, Liceti Fortunio, w: DBI, LXV, 2005, s. 71; całe hasło na s. 69-73).

55 [C. Rinuccini], Descrizione delle feste fatte nelle reali nozze de' Serenissimi principi di Toscana D. Cosimo de' Medici e Maria Maddalena arciduchessa d'Austria, in Firenze, appresso i Giunti, 1608 (por. K. Targosz, op. cit., nr 814 oraz egz. BJ, sygn. Hist 8022 II). O atrybucji tekstu por. G. Melzi, Dizionario di opere anonime e pseudonime di scrittori italiani o come che sia aventi relazione all'Italia, voll. 3, in Milano, coi torchi di Luigi di Giacomo Pirola, MDCCCXLVIII-MDCCCLIX, I, s. 286.

56 In Firenze, appresso i Giunti, 1630 (por. K. Targosz, op. cit., nr 1584). O Bandinellim (zm. przed 1637) por. N. de Blasi, Bandinelli Baccio, w: DBI, V, 1963, s. 692-693. 
lukańczyka Giuseppe Marii Quiliciego ${ }^{57}$, karmelity i akademika wśród Intrepidi z Ferrary. I trionfi - wydrukowane we Florencji w formacie $12^{\circ} \mathrm{w}$ tym samym, 1669, roku, kiedy to wyniesiono na ołtarze beatyfikowaną wcześniej w 1626 roku karmelitankę florencką — służyły uświęceniu kultu, dzięki któremu Maria de’ Pazzi została określona jako „święta dworska”. Warto zaznaczyć, że kult ten dotarł także do Krakowa $^{58}$ i był rozwijany przez mieszkających w nim florentyńczyków ${ }^{59}$. Toskanię na brzegu Wisły ożywia też La Tancia — „wiejska bajka” („favola rusticale") napisana oktawą, autorstwa Michelangela Buonarrotiego młodszego (1568-1647) ${ }^{60}$. Krewny wielkiego artysty był bohaterem kręgów literackich i muzycznych Włoch przełomu XVI i XVII wieku głównie dzięki tworzeniu licznych widowisk teatralnych dla dworu medycejskiego. Wystawiona w maju 1611 roku, w obecności Cosima i Maddaleny, La Tancia pozwalała (w dwóch z czterech intermediów) na pokazanie łowów, którym mężczyźni i kobiety z rodu Medyceuszy oddawali się z wielką pasją na terenach wiejskich.

Konkludując, jeśli zatrzymamy się przez chwilę przed edycjami florenckimi obecnymi w krakowskiej bibliotece, możemy powiedzieć, że widać, jak odbija się w nich życie kulturalne Florencji XVI-wiecznej, która czytała i uwielbiała dzieła takich autorów jak dwaj Villani czy dwaj Pulci (nie przez przypadek, przypomnijmy, przeciwko twórcy Morgante i jego czytelnikom ostro występował Savonarola, namawiając do zniszczenia pism $)^{61}$. Przede wszystkim jednak dostrzegamy w księgozbiorze wyjątkowy obraz Florencji czasów Cosima I. Odznacza się na nim rzeczywiście książęca drukarnia Lorenza Torrentina, odgrywającego (we współpracy z Domenichim) główną rolę, oraz postaci takich twórców

57 I trionfi di Santa Maria Maddalena de’ Pazzi monaca carmelitana nel monastero di S. Maria degli Angioli descritti in compendio dal P. M. Quilici [...], in Firenze, all'insegna della Stella, 1669 (por. K. Targosz, op. cit., nr 1693).

58 Por. J. M. Małecki, Kult św. Magdaleny de Pazzi w barokowym Krakowie, „Folia Historica Cracoviensia”, 1997-1998, 4-5, s. 177-184.

59 Por. R. Mazzei, Ai margini del mondo degli affari: donnee minori in viaggio nell'Europa moderna, w: Donne in viaggio, viaggi in donne. Uno sguardo nel lungo periodo, a cura di R. Mazzei, Firenze 2009, s. 109-110.

60 La Tancia commedia rusticale. Alla serenissima Vittoria principessa d'Urbino graduchessa di Toscana, in Firenze, nella stamperia de' Landini, MDCXXXVIII (por. K. Targosz, op. cit., nr 1371 oraz egz. BJ, sygn. Mag St Dr 591419 I, Liter. włoska 239).

61 Por. P. Viti, Savonarola e i libri, w: Una città e il suo profeta. Firenze di fronte al Savonarola, a cura di G. C. Garfagnini, Firenze 2001, s. 168-169. 
jak Giovio, Casa, Postel i słynny literat wspierany przez władzę medycejską oraz wiodący prym w kulturze miasta - Benedetto Varchi, chociaż ten wybitny akademik figuruje w bibliotece Pinocciego tylko jako tłumacz Seneki. Gusta mieszkających w Krakowie florentyńczyków nie odstają więc, jak się zdaje, zbytnio od upodobań ich współziomków z miasta nad rzeką Arno. Widzimy, na przykład, przypadek Giovia, którego edytorska kariera ściśle związana była z Florencją: przypuszczalnie był on tam w drugiej połowie XVI wieku jednym z najpoczytniejszych autorów $^{62}$. Florenckie edycje z krakowskiego zbioru mówią także o rzeczywistości wydawniczej po Torrentinie uzależnionej od wielu i znacznych ograniczeń, a przede wszystkim — od długiej i niekorzystnej koniunktury, która rozpoczęła się po Soborze Trydenckim i trwała niemal sto lat ${ }^{63}$.

Ograniczenia drukarstwa florenckiego w pełni odbijają się w bibliotece Pinocciego. Florentyńczycy z Krakowa, o ile możemy to osądzić po tym szczególnym zjawisku, kupowali w ojczystym mieście tylko niewielką część książek. Zabierali je potem ze sobą, by rozwijać zainteresowania, zaspokajać głód wiedzy i znosić długie polskie zimy (nie mówiło się też, że wydania florenckie były zawsze nabywane we Florencji). Wielu z nich, faktycznie, często podróżowało do Wenecji i w tym wielkim handlowym ośrodku, gdzie oferta była najbogatsza, a nowości kusiły nawet najbardziej roztargnionych, załatwiało także lekturowe sprawunki.

\section{Edycje lukańskie}

Książki drukowane w Lukce lub pochodzące z niej rękopisy zajmują mało miejsca w bibliotece Pinocciego. Mają raczej wartość sentymentalną i niewiele dodają do bogactwa i różnorodności powiązań kultural-

62 Por. C. Bec, Les livres des florentins (1413-1608), Firenze 1984, s. 87.

63 Por. G. Bertoli, op. cit., s. 87. Badany przez Bertoliego przypadek Giorgia Marescottiego pokazuje „rzeczywistość wydawniczą i Florencję, którą nowoczesne analizy ilościowe i świadectwa współczesnych zgodnie określają jako pozbawioną rynku zdolnego do wchłonięcia wytworu choćby skromnego aparatu produkcyjnego i obciążoną wysokimi podatkami (które przeszkadzały w eksporcie, podnosiły koszt surowców), z mało wykwalifikowaną siłę roboczą i słabo rozwiniętą siecią dystrybucyjną" (ibidem, s. 86). W 1572 roku, kiedy Marescotti rozpoczął działalność drukarską, przejmując oficynę Torrentina, oprócz niego pracowali jeszcze Giunti, Sermartelli, Antonio Padovani i Tosi (por. ibidem, s. 110, przyp. 96). O zaniku przemysłu drukarskiego we Florencji w XVII wieku por. R. L. Bruni, op. cit., s. 325-333. 
nych łączących poszczególne tytuły i autorów. Jeśli jest prawdą, że Lukka, jak pisze Marino Berengo we wprowadzeniu do nowej edycji Nobili e mercanti... była miastem „małej, bardzo małej kultury” ${ }^{64}$, biblioteka Pinocciego potwierdza tę tezę.

Szesnastowieczne edycje Vincenza Busdraghiego, lukańskiego drukarza, który zaczyna działać w 1549 roku i pozostaje aktywny przez pół wieku ${ }^{65}$, wydawcy, między innymi, Aonia Palearia, są rzadkością. Mówiło się już o Opere morali Plutarcha, wyróżniających się w katalogu Busdraghiego, ponieważ typograf ten niewiele uwagi poświęcał edycjom autorów greckich, łacińskich i klasyków literatury włoskiej ${ }^{66}$, a preferował twórców sobie współczesnych. Kolejną książką Busdraghiego jest łacińska wersja żywota Castruccia Castracaniego napisana przez Nicolao Tegrimiego oraz żywota Scypiona Afrykańczyka ułożona przez Antoniego Bendinelliego. Oba teksty przetłumaczył Giusto da Volterra, a Vincenzo Busdraghi opublikował je razem w 1556 roku $^{67}$. Powstała pod koniec XV wieku biografia władcy Lukki, skomponowana przez największego jego zwolennika, nawiązywała do dzieła Bendinelliego, lukańskiego humanisty regularnie bywającego w Modenie i związanego ze środowiskiem Akademii, a potem cenionego nauczyciela w szkołach miejskich w czasie Aonia Palearia ${ }^{68}$. Zainteresowanie osobą Castraniego potwierdza też

64 M. Berengo, Nobili e mercanti nella Lucca del Cinquecento, nuova edizione, Torino 1999 , s. 8.

65 W 1594 roku (lub może w 1595) do przedsiębiorstwa Busdraghiego dołączył Ottaviano Guidoboni, a ostatnią książkę z nazwiskiem Busdraghiego wydrukowano w 1605 roku. Por. L. Mateucci, Saggio di un catalogo delle edizioni lucchesi di Vincenzo Busdragho (1549-1605), „La Bibliofilia”, 1916-1917, XVIII-XIX; A. Cioni, Busdraghi Vincenzo, w: DBI, XV, 1972, s. 508-509; M. Paoli, Busdraghi Vincenzo, w: Dizionario dei tipografi e degli editori italiani. Il Cinqucento, diretto da M. Menato, E. Sandal. G. Zappella, Milano 1997, s. 219-223. Ottaviano Guidoboni kontynuował prace, ale na niższym niż Busdraghi poziomie. Długi spis książek z drukarni Guidoboniego w inwentarzu jego spadkobiercy, Luki, znajduje się w Archivio di Stato (dalej jako AS), Notarile, Atti, parte II, vol. 2265, f. 162 i n., Pompeo Morganti, 5 gennaio 1639.

66 Por. M. Paoli, op. cit., s. 221.

67 Le vite di Castruccio Castrani de gl'Antelminelli principe di Lucca di M. Niccolao Tegrimi lucchese. E del minore Scipione Affricano di M. Antonio Bendinelli da Lucca, in Lucca, per Vincenzo Busdragho, MDLVI (por. K. Targosz, op. cit., nr 1008).

${ }_{68}$ O Bendinellim por. C. Lucchesini, Della storia letteraria del ducato lucchese libri sette, w: Memorie e documenti per servire all'istoria del ducato di Lucca, Lucca, presso Francesco Bertini tipografo ducale, MDCCCXXV-MDCCCXXXI, IX, s. 141-142; 
znajdująca się w bibliotece łacińska Vita Castrucii Tegrimiego (wydanie paryskie z $1546 \mathrm{roku})^{69}$. Nie potrafimy powiedzieć, w jaki sposób książki te dotarły do Krakowa. Kolonia kupców z małej republiki nad brzegami Wisły już istniała, a na początku siedemnastego wieku rozwinęła się, chociaż tak naprawdę pierwszy lukańczyk został cives cracoviensis w 1576 roku $^{70}$. Trzeba dodać, że wspomniane traktaty mogły przyciąnnąć czytelników także spoza świata miejskiego zamkniętego potężnymi murami. Żywot Castruccia łączy się z dużym zainteresowaniem dla przywódcy toskańskiego gibellinizmu, który rządził Lukką w latach 1316-1328, i nie ma wątpliwości, że jego osoba stała się przedmiotem legendy, jaka wywarła wpływ również na Machiavellego. Podobnie było z dziełem Bendinelliego P. Cornellii Scipionis Aemiliani Africani Minoris vita, opublikowanym przez Lorenza Torrentina we Florencji w 1549 roku $^{71}$. Zreszta, jeśli książki drukowane we Florencji, jak prace Egnazio Dantiego, mógł przywieźć do Krakowa Pinocci, to edycje lukańskie równie dobrze mogli transportować do miasta florentyńczycy.

Edycje siedemnastowieczne, a przynajmniej ich część, dotarły do Krakowa, jak można przypuszczać, dzięki jednemu z synów Girolama, Raffaello. Po ukończeniu studiów w Wiedniu (podobnie jak bracia), mieszkał w Lukce u babki ojca przez mniej więcej dziesięć lat i wiemy, że opuszczając miasto przed powrotem do Polski w 1676 roku, zabrał ze sobą skrzynię z książkami ${ }^{72}$. Jest też prawdopodobne, że w ciągu swego długiego pobytu w Lukce posyłał ojcu inne dzieła, zakupione albo w Lukce, albo w pobliskiej Florencji.

Po okresie, w którym w Lukce rozpowszechniły się i trafiły na podatny grunt nowinki religijne tak, że stała się ona jednym z najbardziej heretyckich miast na Półwyspie Apenińskim, od połowy lat siedemdziesiątych XVI stulecia Lukka na nowo zaczęła być uważana za zagłębie

S. Adorni-Braccesi, "Una città infetta”. La repubblica di Lucca nella crisi religiosa del Cinquecento, Firenze 1994, s. 208-216.

69 Castrucii Castracani Antelminelli ducis lucensis vita. Authore Nicolao Tegrimo, Parisiis, apud Iacobum Bogardum sub insigni d. Christophori, 1546 (por. K. Targosz, op. cit., nr 1007). Pierwsza edycja ukazała się w Modenie w 1496 roku. Por. C. Lucchesini, op. cit., IX, s. 187-189.

70 O tym nieszczęsnym sukienniku, który niedługo potem zmarł na dżumę, por. R. Mazzei, Itinera mercatorum..., s. 214 i n.

71 Por. D. Moreni, op. cit., s. 4042.

72 „Conto di spesa di condotta d'una cassa libri et altro dal Luca a Cracovia”; Kraków, Archiwum Pinoccich, Inventario del 1679 de’ mazzi si scritture di casa, IT 385, s. 3. 
ortodoksji, co znalazło swoje odbicie w książkach obecnych w bibliotece Pinocciego. Religijność spod znaku kontrreformacji, skupioną na zbiorowej dewocji i zewnętrznych ceremoniach, reprezentuje kilka dzieł o tematyce religijnej. Na pierwszym miejscu wymieńmy kult Świętego Oblicza i związaną z nim Historia del Volto Santo di Lucca, detto comunemente Santa Croce Cesarego Franciottiego ${ }^{73}$. Z kultem Świętego Wizerunku związane było jedno z najważniejszych lukańskich świąt procesja, która odbywała się co roku, 13 września, a jej przebieg już od XIV wieku skrupulatnie określały statuty i urzędowe zarządzenia ${ }^{74}$. Oddawanie czci Świętemu Obliczu tradycyjnie łączyło kupieckie wspólnoty wywodzące się z Lukki i rozsiane po Italii i Europie. Inne tytuły odsyłają do miłosierdzia maryjnego także czczonego w mieście ${ }^{75}$; chodzi tu o dwie książeczki: Notitie della miracolosa madonna del Sasso di Lucca augustynianina Donata Donatiego ${ }^{76}$ oraz Il Frontale della Vergine Santissima Benedetta Burlamacchiego ${ }^{77}$. Ze środowiskiem miejskim związane były także Successi della santa casa di Loreto odnoszące się do kultu loretańskiego, który praktyka dewocyjna kontrreformacji spopu-

73 Lucca, Baldassare Del Giudice, [b. r. wyd.] (por. K. Targosz, op. cit., nr 1617). O Cesare Franciottim i Congregazione dei Chierici della Madre di Dio por. C. Lucchesini, op. cit., X, s. 111; E. del Gallo, Franciotti Cesare, w: DBI, L, 1998, s. 159-160. W bibliotece znajduje się także inne dzieło Franciottiego pt. Il giovanetto christiano cioè Instituzione de' i giovanetti alla devotione [...], in Venetia, presso Sebastiano Combi, MDCXVI (por. K. Targosz, op. cit., nr 1616).

74 Por. A. Guerra, Notizie storiche del Volto Santo di Lucca, Lucca, tipografia arcivescovile San Paolino, 1881; Il Volto Santo. Storia e culto, a cura di C. Baracchini, M. T. Filieri, Lucca 1982.

75 Por. M. P. Paoli, Nell'Italia delle „vergini belle”: a proposito di Chiara Matraini e di pietà mariana nella Lucca di fine Cinquecento, w: Religione, cultura e politica nell'Europa dell'età moderna. Studi offerti a Mario Risa dagli amici, a cura di C. Ossola, M. Verga, M. A. Visceglia, Firenze 2003, s. 538-545.

${ }^{76}$ Notitie della miracolosa madonna del Sasso di Lucca, posta nella chiesa di S. Agostino, raccolte dal padre Donato Donati [...], in Lucca, appresso Francesco Marescandoli, MDCLVII (por. K. Targosz, op. cit., nr 1598). O Donatim (zm. 1658) por. C. Lucchesini, op. cit., X, s. 94.

77 Il Frontale della Vergine Santissima già ampliato, \& hora rinovato \& diviso in tre capitoli [...] Di F. Benedetto Burlamacchi maestro carmelitano, in Lucca, appresso Iacinto Paci \& c., 1660 (por. K. Targosz, op. cit., nr 1575). 
laryzowała, podobniej jak cieszące się dużą popularnością pielgrzymki do Loreto $^{78}$.

Z innych dzieł Donatiego w bibliotece znalazła się także Devotio de Christi Domini passione et de doloris eiusdem Sanctissimae Matris Mariae $^{79}$. Z utworów Guida Vanniniego, który prowadził w mieście szkołę wymowy i poezji oraz miał doświadczenia rzymskie, Pinocci posiadał De arte amandi Deum libri tres ${ }^{80} . \mathrm{Z}$ popieraną przez kontrreformację twórczością mającą na celu regulowanie zachowań moralnych i społecznych łączy się anonimowy katechizm pod tytułem Dottrina christiana per insegnarsi da i curati nelle loro parocchie a’ fanciulli. W rzeczywistości jego autorem był Giovanni Leonardi ${ }^{81}$, lukańczyk, który założył w 1574 roku Congregazione dei „preti riformati della beata Vergine” (w następnym wieku przekształciła się ona w Congregazione dei Chierici Regolari della Madre di Dio).

Wymienione wyżej książki (Il Frontale della Vergine Santissima (1660) Burlamacchiego, Successi della santa casa di Loreto (1662), Devotio de Christi Domini passione (1670) ojca Donatiego i Dottrina christiana ojca Leonardiego (1670)) zaliczyć trzeba do literatury dewocyjnej bez zbytnich ambicji, wydawanej w mniejszych formatach w Lukce w latach sześćdziesiątych i siedemdziesiątych XVII stulecia oraz pochodzącej przede wszystkim z typografii Iacinta Paciego. Drukarnia ta kontynuowała działalność oficyny Baldassara Del Giudice (czynnej

${ }_{78}$ O sukcesie przewodników dla pielgrzymów pod. F. Grimaldi, Il libro lauretato, secoli XV-XVIII, Macerata 1994. O przewodniku posiadanym przez Pinocciego por. ibidem, s. 204, nr 174: [B. Pierotti], Successi della Santa Casa di Loreto ristretti in compendio e presentati al popolo e città di Lucca, da PP. Di S. Maria Cortelandini della Congregazione della Madre di Dio, in Lucca, appresso Iacinto Paci, 1662 (por. K. Targosz, op. cit., nr 1720).

79 Lucae, H. Pacius, 1673 (por. K. Targosz, op. cit., nr 1597).

80 Guidonis Vanninii i. c. civis lucensis, et romani. De arte amandi Deum libri tres, Lucae, apud Octavianum Guidobonium, 1632 (por. K. Targosz, op. cit., nr 1475). Dzieło musiało zostać docenione, skoro cztery lata później wydano je po raz drugi ( $D e$ arte amandi Deum Guidonis Vanninii civis lucensis lib. 3, Lucae, apud Balthasari de Iudicibus, 1636). O Vanninim (1571-1654) por. C. Lucchesini, op. cit., X, s. 59-60. W bibliotece znajduje się także Carminum libri quattuor Vanniniego (Lugduni, sumptibus Horatii Cardon, 1611; por. K. Targosz, op. cit., nr 1474).

81 Dottrina christiana per insegnarsi da i curati nelle loro parocchie a' fanciulli della città di Lucca e sua diocesi, Lucca, appresso Iacinto Paci, 1670 (por. K. Targosz, op. cit., nr 1599). O autorstwie Leonardiego por. G. Melzi, op. cit., III, s. 502. 
w pierwszej połowie XVII wieku) ${ }^{82}$. Od 1653 roku rozpoczęła działalność drukarnia Marescandoliego, która funkcjonowała przez ponad 150 lat (do $1805 \mathrm{roku}$ ), publikowała bardzo dużo mniej istotnej literatury $^{83}$ : chętnie czytane teksty popularne, w małym formacie i skromnej szacie graficznej, dzieła dewocyjne i służące doskonaleniu duchowemu, żywoty świętych, księgi przeznaczone dla proboszczów sprawujących pieczę nad religijnym wychowaniem wiernych. „Appresso Francesco Marescandoli” zostały wytłoczone Notitie della miracolosa madonna del Sasso di Lucca (1657) Donatiego i, przede wszystkim, mająca wielkie powodzenie książeczka, która bardzo długo cieszyła się uznaniem, zatytułowana Avvisi di buone creanze cavati da Monsignor Giovanni della Casa ed altri buoni autori $(1658)^{84}$. Przeznaczone dla dzieci Avvisi... stanowiły kompilację zasad dobrych manier, jakie narodziły się w Italii na początku XVII stulecia. W domu Pinocciego, jak widzieliśmy, znajdowały się dwie szesnastowieczne edycje Galateo. Avvisi... lepiej służyły do szlifowania poprawnego zachowania opierającego się na cnocie głównej zasadzie indywidualnego postępowania - i czynieniu wszystkiego zgodnie z zasadami stosowności. Krótko mówiąc, chodzi o tekst z biblioteki rodziny, która w ciągu życia jednego pokolenia awansowała społecznie w niewiarygodny sposób i wysyłała swoich synów na studia do Wiednia.

Między siedemnastowiecznymi wydaniami znajdują się także dzieła z kręgu publicystyki polityczno-religijnej związanej z interdyktem

82 W chwili śmierci Baldassara del Giudice w czerwcu 1650 roku jego brat Gasparo podjął decyzję o kontynuowaniu działalności drukarni i powierzył ją Iacintowi Paciemu i Bernardinowi Pieriemu. „Compagna o negotio di libraria et stampa [...] sotto nome di Iacinto Paci et Bernardino Pieri et compagni” z dniem 1 stycznia 1652 została zarejestrowana w Corte dei mercanti. Por. Lucca, AS, Corte dei mercanti, Libri delle Date, vol. 90, k. 161v-162v. Inwentarz wydrukowanych książek i całej reszty: odbitek, papieru, czcionek miedzianych, drewnianych i ,innych przedmiotów z tej księgarni i drukarni” opiewał na sumę 5626 skudów, 1 solda, 4 denarów.

83 Por. L. Godani, I Marescandoli di Lucca, 1653-1805, „Culture del testo”, III, 1997, s. 29-60.

84 In Lucca, appresso Francesco Marescandoli, 1658 (por. K. Targosz, op. cit., nr 429). O nadzwyczajnym sukcesie książeczki, której autora lub redaktora i pierwszej edycji nie znamy, por. I. Botteri, Un manuale europeo: gli „Avvisi di buone creanze cavati da Monsignor Giovanni della Casa ed altri buoni autori". La storia, il testo, le edizioni, w: Le forme del vivere civile tra Medioevo e modernità. Temi, fonti, storiografia, a cura di I. Botteri, D. Romagnoli, Roma 2003 [„Cheiron”, XIX, 38], s. 109-142. 
z 1640 roku. Biskup Marcantonio Franciotti, pochodzący z zamożnej rodziny kupieckiej, poróżnił się z Offizio sopra l'Abbondanza z powodu handlu zbożem, który chciał uwolnić na terenach znajdujących się pod jego jurysdykcją i którym zajmowali się jego dwaj bracia: Bartolomeo i Nicolao. Biskup apelował do papieża Urbana VIII, aby ten zagroził miastu karą, i - mając przeciwko sobie całą oligarchię miejską — pośrednio doprowadził do aresztowania swych krewnych ${ }^{85}$.

Obronę przed oskarżeniami miotanymi przez apostolskiego komisarza Cesarego Raccagniego rząd lukański powierzył prawnikowi Lelio Altogradiemu. Ten napisał Relatione i Difesa oraz opublikował utwory pod fałszywym nazwiskiem Girolama Beraldiego a Lucca i ze wskazaniem na niewłaściwe miejsce druku - Kolonię ${ }^{86}$. Teksty te krążyły poza Lukką i jakimiś drogami dotarły także do Krakowa.

Aby skompletować wykaz książek nie pozostaje nam nic innego, jak dodać do biblioteki Le zimbellate al zimbello mediolańczyka Carla Torre. Warto by zrekonstruować drogę, która doprowadziła autora do wydania w Lukce w 1641 roku „apresso Castacagnina”, z czego nic nie wynika, polemiki z Giovannim Battistą Livizzanim ${ }^{87}$, twórcą „książczyny wydrukowanej niedawno i szybko, zatytułowanej Zimbello, over Italia schernita" ${ }^{88}$, a raczej Zimbello, o vero l'Italia schernita. Jeśli rzeczywiście bliżej nieznany mediolańczyk Torre przybył do Lukki, aby obrzucić obelgami Livizzaniego, można pomyśleć, że dokonał takiego wyboru,

85 Por. R. Mazzei, La questione dell'interdetto a Lucca nel secolo XVII, „Rivista storica italiana", LXXXV (1973), fasc. I, s. 167-185; D. Busolini, Franciotti Marco Antonio, w: DBI, L, 1998, s. 162-163.

86 Relatione d'alcuni successi occorsi alla republica di Lucca negl'anni MDCXXXVIII. XXXIX. XL dopo la venuta a quel vescovato del Sig. cardinal Franciotti. Scritta fedelmente dal Girolamo Beraldi Gentil'huomo lucchese, in Colonia, MDCXL (por. K. Targosz, op. cit., nr 764); Difesa per la republica di Lucca contro le censure fulminate da Monsig. Cesare Raccagni. Composta da Girolamo Beraldi gentil'huomo lucchese, dottore, e theologo, in Colonia, MDCXL (por. K. Targosz, op. cit., nr 763). O dziełach wydrukowanych pod fałszywym nazwiskiem autora za publiczne pieniądze por. M. Parenti, Dizionario dei luoghi di stampa falsi, inventati o supposti, Firenze 1951, s. 51.

87 [C. Torre], Le zimbellate al zimbello, ovvero l'Italia riconosciuta, in Lucca, apresso Castacagnina, MDCXLI, s. 2 (por. K. Targosz, op. cit., nr 509). O autorstwie Torrego (zm. 1679) por. G. Melzi, op. cit., III, s. 273.

88 Il zimbello, o vero la Italia schernita, in San Marino, presso Fillo Etimagoro, MDCXLI. Miejsce druku jest fałszywe. Szerzej na ten temat por. M. Parenti, op. cit., s. 181-182. O dziełach tego typu por. V. di Tocco, Ideali d'indipendenza in Italia durante la preponderanza spagnuola, Messina 1926, s. 242-246. 
ponieważ miasto było jednym z tych miejsc w Italii, gdzie mocno czuć było antyhiszpańskiego ducha.

Wtedy, kiedy Pinocci umocnił swoją pozycję ekonomiczną i społeczną w Polsce tak bardzo, że zaczął świadczyć usługi na dworze królewskim, jego związki z Lukką, gdzie z całej familii pozostała tylko jedna siostra, zaczęły się rozluźniać. Prawdopodobnie te ekonomiczne utrzymywały się jeszcze długo z powodu importu cennych tkanin tak bardzo pożądanych przez szlachtę w Polsce. Te osobiste, doprowadziły, jak widzieliśmy, do tego, że jeden z synów przebywał w Lukce przez dziesięć lat, chociaż nic nie wskazuje bezpośrednio na to, by w tym okresie poświęcał się handlowi. Nieliczne edycje lukańskie zebrane w „camera della libraria” w domu Pinocciego pokazują więc miłość do rodzinnego miasta skazaną na wygaśnięcie i to nie tylko z powodu odległości geograficznej.

Uderza, że żadne z wydań lukańskich i niewiele florenckich nie pojawia się $\mathrm{w}$ tych, znanych nam, spisach ksiąg przygotowanych przez samego Pinocciego, które, dając wyobrażenie o jego lekturach, mogą lepiej naświetlić jego wybory. Dla osoby takiej jak on, uważnie śledzącej nowości („curieux de tout” ${ }^{89}$ określał go w 1658 roku Pierre des Noyers, francuski sekretarz królowej Marii Ludwiki), książki wydrukowane w malutkiej republice, skromniutkie i czasem o niewielkiej liczbie stron, musiały być - w porównaniu z głośnymi nazwiskami i tytułami związanymi z innymi kontekstami kulturowymi — przedmiotami o sentymentalnej wartości, być może postawionymi w głębi półki, przykrytymi przez kurz.

Podobnie jak w przypadku edycji florenckich, także i w odniesieniu do edycji lukańskich, jak się zdaje, można powiedzieć, że krakowska biblioteka pokazuje niewyraźny fragment obrazu drukarstwa lukańskiego XVI-XVII wieku. Za początkowym dbaniem o jakość cechującym Busdraghiego, który zasłużył się dla ustabilizowania działalności wydawniczej w Lukce, wcześniej mało znaczącej, postępowała działalność typografów siedemnastowiecznych o mniejszej sławie i skromniejszej produkcji zarówno pod względem ilości, jak i jakości. Chodzi o takie postaci jak: następca Busdraghiego (zm. 1601) — Ottaviano Guidobo-

89 Lettres de Pierre des Noyers secrétaire de la reine de Pologne Marie-Louise de Gonzague princesse de Mantove et de Nevers pour servir à l'histoire de Pologne et de Suède de 1655 à 1659, Berlin 1859, s. 524, 
ni, następca Guidoboniego (zm. 1639) - Baldassare Del Giudice i, wreszcie, następca Del Giudice (zm. 1650) — Iacinto Paci.

Do tych drukarzy i jeszcze Marescandoliego, aktywnych od 1653 roku, można ograniczyć drukarstwo lukańskie w stuleciach XVI i XVII ${ }^{90}$. Być może nie byłoby jednak od rzeczy spróbować zweryfikować, czy przez przypadek ta tradycja, choć tak słaba, nie miała udziału w niesamowitym przedsięwzięciu wydawniczym, jakim był druk lukańskiej Enciclopedia.

Przełożyła Marta Wojtkowska-Maksymik

\section{Florentine and Lucca Editions in the Cracovian Library in the Seventeenth century}

The article describes Florentine and Lucca editions located in the Cracov library of Lucca citizen Girolam Pinocci (1612-1676). The author presents individual issues and the most important printers of Florence and Lucca, whose books are present in Pinocci's collection. She also focuses on the works of authors covering different fields of knowledge, such as medicine, astronomy and geography. Attention is drawn to the presence in the collection of religious works typical of the Counter-Reformation period, historical chronicles and poems by the Pulci brothers. Moreover, a lot of attention has been paid to the ways books published in Italy reached seventeenth-century Cracow.

Translated by Agnieszka White

$90 \quad$ Do wymienionych wyżej nazwisk można dodać jeszcze kilka innych, a wśród nich działającego pod koniec XVI wieku drukarza Mattea Galassiego. Por. F. Ascarelli, op. cit., s. $144,145$. 